\title{
Identifikasi Tungau Debu Rumah di Tempat Tinggal Pasien Dermatitis Atopik RSUD Petala Bumi Pekanbaru
}

\author{
Suri Dwi Lesmana ${ }^{1 *}$, Deon Pradana Putra $^{2}$, Alida Widiawaty ${ }^{3}$
}

\begin{abstract}
House dust mite have an important role as an allergens in allergic diseases such as atopic dermatitis. Atopic dermatitis is inflammation of the skin with itching, chronic and recurrent symptoms. The aim of this study was to find out the description of house dust mites in the house of patients at Petala Bumi Hospital. Design of study was a crosssectional. This study was occured from May-June 2018 in the Laboratory of Parasitology and involved 30 atopic dermatitis patients with consecutive sampling technique. Results is showed $100 \%$ of atopic dermatitis patients house were positive for house dust mites, $63.3 \%$ of patients behaved badly in hygiene which affected degree of house dust mite spread. Conclusions of this study showed that a whole place of atopic dermatitis patients house was positive for house dust mite, most of patients behaved badly in hygiene which affected degree of house dust mite spread.
\end{abstract}

Keywords: atopic disease, degree of spread, hygiene.

Tungau debu rumah (TDR) memiliki peranan penting sebagai sumber alergen pada penyakit alergi seperti asma, rinitis alergi, dermatitis atopik, dan penyakit atopi lainnya. Tungau debu rumah mempunyai bagian tubuh yang mengandung bahan alergen. Kutikula, organ seks dan saluran cerna merupakan bagian tubuh dari TDR yang bersifat alergen. Tungau dapat ditemukan pada beberapa tempat terutama di tempat tidur, karpet dan lantai. ${ }^{1}$

Sumber alergen yang ditemukan dari tungau debu rumah dapat dikelompokkan menjadi 24 grup. $\operatorname{Der} p 1$ dan $\operatorname{Der} f 1$ dan kelompok 2 (Der $p 2$ dan Der $f$ 2) dianggap sebagai alergen utama tungau debu rumah. Alergen tungau dari kelompok I dan II secara klinis berkaitan dengan penyakit alergi, salah satunya dermatitis atopik. ${ }^{2,3}$

Dermatitis atopik (DA) adalah peradangan pada kulit dengan gejala rasa gatal, berlangsung kronik dan berulang, sering terjadi pada penderita ataupun keluarga yang mempunyai riwayat atopi seperti asma bronchial dan atau rhinitis alergi. ${ }^{2}$ Atopi

\footnotetext{
* Korespondensi penulis : email : dr.soerie@gmail.com

1 KJFD Parasitologi Fakultas Kedokteran Universitas Riau

2 Mahasiswa Fakultas Kedokteran Universitas Riau

3 KJFD Biologi Fakultas Kedokteran Universitas Riau dan KJFD Ilmu Kesehatan Kulit dan Kelamin Fakultas Kedokteran Universitas Riau
}

adalah suatu keadaan meningkatnya risiko seseorang terhadap penyakit alergi. ${ }^{4}$ Hasil penelitian yang dilakukan oleh Davin di RSUP Haji Adam Malik Medan didapatkan perempuan lebih banyak (56\%) dari laki-laki (44\%). Serta kelompok usia tertinggi pada penderita DA adalah usia diatas 23 tahun yaitu 20 orang $(40 \%){ }^{5}$

Tujuan penelitian ini untuk mengetahui bagaimana gambaran tungau debu rumah di tempat tinggal pasien dermatitis atopik RSUD Petala Bumi Pekanbaru.

\section{METODE}

Jenis penelitian ini merupakan penelitian deskriptif dengan desain cross sectional, tujuannya untuk mengetahui gambaran tungau debu rumah di tempat tinggal pasien dermatitis atopik RSUD Petala Bumi Pekanbaru. Penelitian ini dilakukan pada bulan Mei - Juni 2018. Populasi pada penelitian ini adalah debu dari tempat tinggal pasien dermatitis atopik yang berobat di RSUD Petala Bumi Pekanbaru periode 2017. Jumlah sampel pada penelitian ini adalah 30 pasien DA. Data dianalisis dengan menggunakan statistik deskriptif dalam bentuk persentase dan distribusi frekuensi 


\section{HASIL}

Hasil identifikasi TDR di tempat tinggal pasien DA dapat dilihat pada tabel 1 berikut.

Tabel 1. Identifikasi tungau debu rumah $(\mathrm{N}=30)$

\begin{tabular}{lll}
\hline Hasil identifikasi & $\mathrm{N}$ & $\%$ \\
\hline Positif & 30 & 100 \\
Negatif & 0 & 0 \\
\hline Total & 30 & 100 \\
\hline
\end{tabular}

Berdasarkan tabel 1 dapat dilihat bahwa dari 30 tempat tinggal yang diidentifikasi, seluruh tempat tinggal pasien DA positif tungau debu rumah.
Hasil penemuan TDR berdasarkan lokasi pengambilan debu di tempat tinggal pasien DA dapat dilihat pada tabel 2 berikut.

Tabel 2 Lokasi ditemukan TDR(N=30)

\begin{tabular}{lll}
\hline Lokasi ditemukan TDR & $\mathrm{N}$ & $\%$ \\
\hline Kamar tidur & 30 & 100 \\
- Positif & 0 & 0 \\
- Negatif & & \\
Ruang keluarga & 24 & 80 \\
- Positif & 6 & 20 \\
- Negatif & \\
\hline
\end{tabular}

Derajat penyebaran TDR di tempat tinggal pasien DA dapat dilihat pada tabel 3 berikut.

Tabel 3 Derajat penyebaran TDR $(\mathrm{N}=30)$

\begin{tabular}{lll}
\hline Derajat penyebaran ditemukan TDR & N & $\%$ \\
\hline Tinggi & 24 & 80 \\
Rendah & 6 & 20 \\
\hline Total & 30 & 100 \\
\hline
\end{tabular}

Berdasarkan tabel 3. dapat dilihat bahwa setelah dilakukan penjumlahan lokasi ditemukan derajat penyebaran tungau debu rumah, $80 \%$ tempat tinggal pasien DA tergolong tinggi dan $20 \%$ memiliki tingkat persebaran rendah.

Tabel 4. Gambaran perilaku higiene pasien DA $(n=30)$

\begin{tabular}{lll}
\hline \multirow{2}{*}{ Perilaku higiene } & \multicolumn{2}{l}{ Pasien DA } \\
\cline { 2 - 3 } & $\mathrm{N}$ & $\%$ \\
\hline Baik & 11 & 36,7 \\
Buruk & 19 & 63,3 \\
\hline
\end{tabular}

Berdasarkan tabel 4. dapat dilihat bahwa perilaku pasien DA terkait keberadaan TDR adalah
Gambaran perilaku higiene pasien DA terkait keberadaan tungau debu rumah dapat dilihat pada tabel berikut. 
Berdasarkan tabel distribusi perilaku higiene dapat dilihat bahwa perilaku higiene pasien DA yang masih dikategorikan baik adalah perilaku mengepel lantai dengan menggunakan cairan desinfektan, perilaku membersihkan tempat tidur setiap selesai digunakan, perilaku membersihkan ventilasi, serta perilaku membersihkan kipas minimal sebulan sekali dan AC di servis setiap enam bulan. Selain perilakuperilaku tersebut, perilaku higiene pasien DA adalah buruk.

Tabel 5. Distribusi perilaku higiene $(\mathrm{n}=30)$

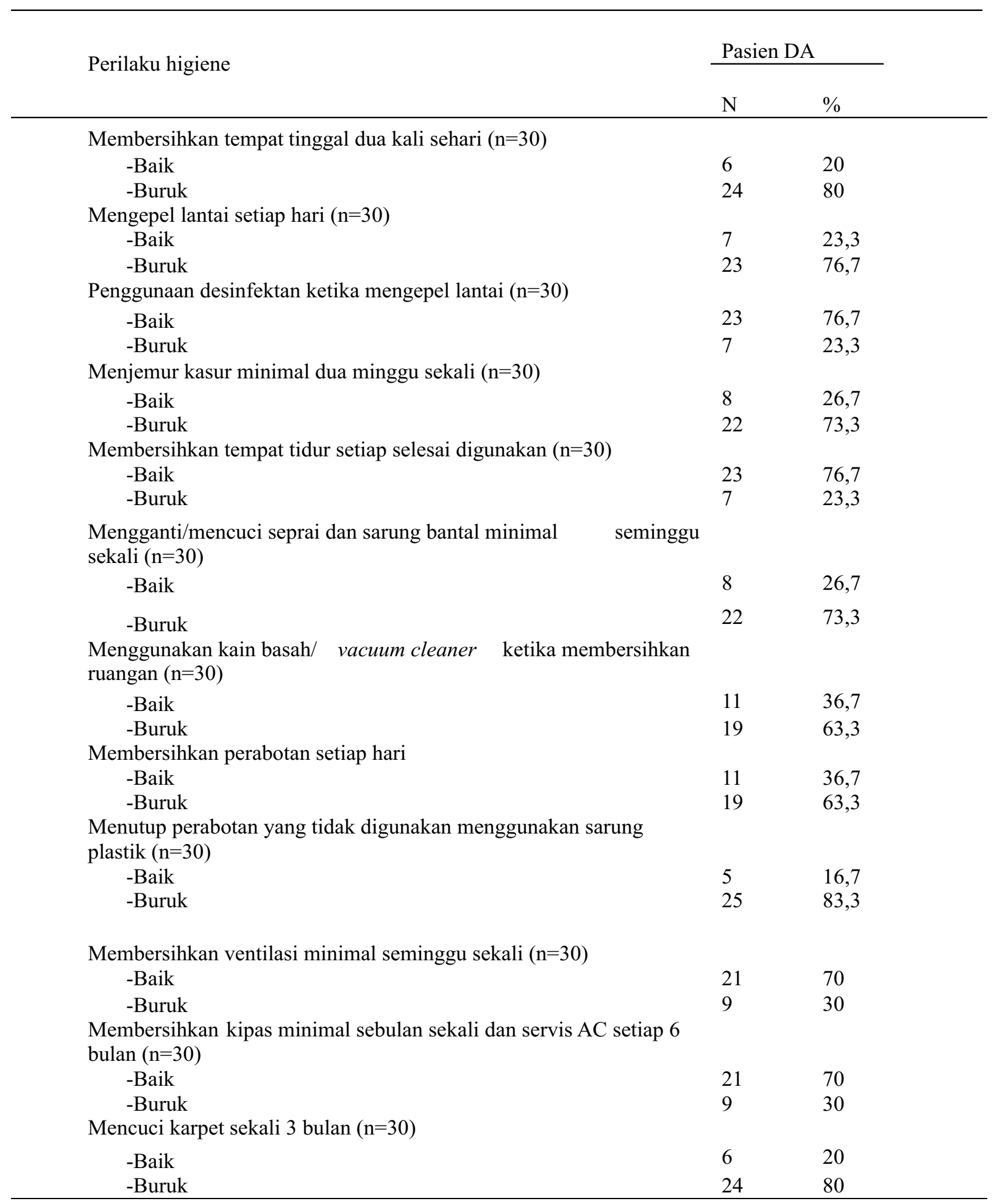




\section{PEMBAHASAN}

Penelitian ini didapatkan seluruh tempat tinggal pasien DA positif TDR dari 30 rumah yang diidentifikasi. Penelitian ini mengambil debu pada beberapa titik di ruang kamar dan ruang keluarga. Lokasi pengambilan seperti di bawah karpet, sudut ruangan, di bawah kursi atau sofa dan kasur serta ventilasi. Hasil ini memperlihatkan TDR dapat ditemukan di semua tempat tinggal pasien DA yang tentunya akan berisiko bagi pasien yang tersensitisasi oleh TDR. Bagian tubuh TDR yang dapat menjadi alergen adalah kutikula, organ seksual, saluran cerna dan kotoran. Partikel kotoran mengandung proporsi terbesar dari alergen tungau. ${ }^{8}$

Alergen TDR Der $p I$ dan Der $f I$ terdapat dalam konsentrasi tinggi pada feses. Alergen ini spesifik terhadap IgE penderita DA, sehingga terjadi kelainan fungsi sawar kulit yang mengakibatkan peningkatan trans epidermal water loss (TEWL). Kondisi ini akan mengakibatkan kulit kering sehingga memudahkan induksi pruritus pada DA. Serabut saraf sensorik juga mengalami penurunan ambang rasa terhadap stimulus pruritogenik. ${ }^{2}$ Hasil penelitian ini menunjukkan bahwa tingginya penemuan TDR dapat mengakibatkan kontaknya alergen TDR pada kulit, sehingga dapat menimbulkan gejala klinis DA.

Seluruh rumah yang diperiksa ditemukan positif TDR dapat dikaitkan dengan habitat TDR yang dapat hidup di berbagai tempat di rumah. TDR hidup bercampur dengan debu yang terdapat di kasur, karpet, sofa maupun peralatan rumah tangga lainnya. Sewaktu penelitian dilakukan memang hampir di seluruh rumah masih terdapat debu rumah di tempat-tempat diambilnya sampel debu. Hal ini tentu juga akan berkaitan dengan jumlah tungau yang ditemukan.

Kondisi yang hangat, lembap dan gelap merupakan media yang baik untuk pertumbuhan TDR. Tungau memerlukan suhu ruangan $25^{\circ} \mathrm{C}-30^{\circ} \mathrm{C}$ dan kelembapan udara 70-80\% untuk hidupnya. Iklim Kota Pekanbaru pada umumnya beriklim tropis. Suhu udara maksimum berkisar antara $30,5^{\circ} \mathrm{C}$ $33,7^{\circ} \mathrm{C}$ dan suhu minimum berkisar antara $21,6^{\circ} \mathrm{C}$ $23,9^{\circ} \mathrm{C}$. Kelembapan rata-rata berkisar antara 69$81 \%{ }^{9}$ Hal ini tentu dapat menjadi salah satu faktor hampir di semua tempat tinggal pasien ditemukan tungau debu rumah karena suhu dan kelembapan Kota Pekanbaru yang sesuai untuk perkembangan tungau.

Tungau berkembang melalui lima tahapan metamorfosis tidak sempurna yaitu telur, larva, protonimfa, tritonimfa dan dewasa. Waktu yang diperlukan pada perkembangan tungau dari telur hingga bentuk dewasa adalah sekitar 19-35 hari. Stadium dewasa jantan berumur 60-80 hari, sedangkan tungau betina 100-150 hari. ${ }^{6,10}$

Teori tersebut menyebutkan bahwa TDR dapat menjadi alergen setelah dewasa, yang memerlukan waktu sekitar 19-35 hari, dengan kata lain siklus hidup tungau yang cepat dapat menyebabkan tingginya tingkat perkembangbiakan tungau, sehingga pembersihan rumah harus dilakukan secara berkala dari tempat-tempat perkembangbiakan tungau debu. Pada penelitian ini ditemukan seluruh tempat tinggal pasien positif tungau debu rumah ini mungkin dapat disebabkan perilaku penghuni rumah dalam pengendalian dan pemahaman tentang pengendalian tungau debu rumah belum optimal.

Hasil penilitian ini sesuai dengan hasil penelitian Ponggalunggu et al yang memeriksa tungau debu rumah pada rumah penderita penyakit alergi. Pemeriksaan yang dilakukan pada 32 rumah mendapatkan hasil semua rumah positif tungau debu rumah. ${ }^{11}$ Hal ini juga serupa dengan hasil yang didapatkan oleh Worang I. et al dan Kokali F.M. et al. Worang I et al memeriksa 71 rumah dan hasil yang didapatkan 61 rumah positif tungau debu rumah. ${ }^{12,13}$ Penelitian yang dilakukan Kokali et al mendapatkan hasil sebanyak 50 rumah postif tungau debu rumah dari 78 rumah yang diperiksa. ${ }^{13}$

Pemeriksaan pada debu rumah menampilkan hasil bahwa TDR hampir ditemukan di seluruh bagian rumah yang dilakukan pemeriksaan. Hal ini tentu tidak terlepas dengan kehidupan manusia yang berlangsung di rumah dan makanan utama tungau yang berasal dari manusia, keadaan rumah yang sangat cocok sebagai tempat perkembangan dan kelangsungan hidup tungau, tempat-tempat yang sulit dijangkau ketika membersihkan rumah serta perilaku penghuni terhadap pengendalian TDR yang belum dilakukan dan dipahami secara optimal.

Pemeriksaan debu rumah ditemukan TDR di seluruh bagian ruang kamar pada rumah yang diteliti. Hal ini dikarenakan sebagian besar waktu manusia berada di kamar tidur yaitu sekitar 6-8 jam perhari. ${ }^{14}$ 
Hasil ini sesuai dengan penelitian Worang I mendapatkan hasil kamar tidur lebih banyak positif tungau debu rumah dari ruang keluarga. Pemeriksaan pada 71 rumah masing-masing 71 kamar tidur dan 71 kamar keluarga didapatkan hasil 46 kamar tidur dan 42 ruang keluarga postif tungau debu rumah. ${ }^{12}$ Hal ini dapat disebabkan karena kamar tidur khususnya kasur merupakan tempat yang paling disukai tungau karena tersedia sumber makanan tungau berupa epitel kulit manusia dan kondisi ruangan yang sesuai untuk perkembangbiakan tungau.

Pemeriksaan debu rumah pada ruang keluarga ditemukan TDR di ventilasi, sudut lantai, di bawah karpet dan sofa karena jumlah debu yang berada di tempat-tempat tersebut cukup banyak dan tidak terjangkaunya tempat-tempat tersebut pada saat membersihkan rumah. Hasil penelitian ini berbeda dengan penelitian yang didapatkan oleh Kristin S.P dan Kokali F.M, TDR lebih banyak ditemukan di ruang keluarga daripada kamar tidur. ${ }^{13,15}$ Penelitian oleh Ponggalunggu juga mendapatkan hasil yang berbeda yaitu ruang keluarga, sofa adalah tempat terbanyak ditemukan tungau debu rumah dibandingkan tempat tidur dan lantai kamar tidur. Pada sofa ditemukan 23 tempat positif, sedangkan pada tempat tidur dan lantai kamar tidur adalah 21 dan 16 tempat. ${ }^{11} \mathrm{Hal}$ ini dapat disebabkan karena kebiasaan sebagian besar masyarakat dalam membersihkan rumah masih belum optimal, masih banyak yang jarang mengepel lantai, pengunakan kemoceng untuk mengelap perabotan, yang mengakibatkan debu beterbangan. Kebiasaan ini tidak dapat mengurangi populasi TDR di tempat tinggal pasien sehingga dapat menjadi faktor pencetus terjadinya DA. ${ }^{16}$

Hasil penelitian ini menggambarkan lamanya paparan TDR pada pasien DA saat berada diruang kamar. Hal ini sesuai dengan pembahasan sebelumnya, yaitu semakin sering terpapar alergen TDR pada kulit dapat menimbulkan gejala klinis DA.

Penelitian ini mendapatkan hasil $80 \%$ tempat tinggal pasien DA termasuk kategori derajat penyebaran tungau tinggi dan $20 \%$ rendah. Derajat penyebaran tungau tinggi jika dari pengambilan debu yang dilakukan terdapat $2 / 2$ positif ditemukan TDR di tempat pengambilan debu pada ruang kamar, dan ruang keluarga. Penyebaran tungau rendah jika dari pengambilan debu yang dilakukan ditemukan $1 / 2$ positif TDR di tempat pengambilan debu pada ruang kamar atau ruang keluarga. Tingkat temuan identifikasi ini ditetapkan sendiri oleh peneliti karena belum ada penelitian yang sama sebelumnya.

Hasil ini memperlihatkan tungau debu rumah memiliki populasi yang tinggi di tempat tinggal pasien DA dan akan meningkatkan risiko pasien DA itu tersebut khususnya yang tersentisasi oleh TDR. Oleh karena itu perlu dilakukan pencegahan atau pengendalian untuk menangani hal tersebut. Seperti bahasan sebelumnya jumlah lokasi ditemukan TDR yang tinggi ini mungkin dapat dipengaruhi oleh banyak faktor seperti keadaan rumah yang cocok untuk perkembangan tungau debu rumah, pembersihan rumah yang belum dilakukan secara optimal, tempattempat yang sulit dijangkau ketika membersihkan rumah dan cara membersihkan debu rumah yang belum sesuai dengan yang dianjurkan.

Perilaku higiene pasien DA berperan penting dalam mengurangi alergen yang dapat memicu terjadinya DA. Sebagian besar waktu manusia berada di kamar tidur yaitu sekitar 6-8 jam perhari. ${ }^{14}$ Kegiatan kebersihan kamar tidur ataupun ruangan di tempat tinggal dapat membantu menghindari pemicu timbulnya DA. Penelitian ini menggambarkan perilaku higiene pasien DA terkait keberadaan tungau debu rumah ditentukan berdasarkan hasil penilaian menggunakan kuesioner.

Berdasarkan penelitian ini, perilaku higiene pasien DA terkait keberadaan TDR didapatkan perilaku higiene yang buruk berjumlah $63,3 \%$. Hasil ini menunjukkan bahwa sebagian besar perilaku higiene pasien DA masih tergolong buruk sehingga dapat memicu reaksi alergi. Hal ini disebabkan oleh masih kurangnya pengetahuan pasien tentang pengendalian TDR dan membersihkan rumah yang baik dari debu. Penelitian ini mendapat hasil yang sejalan dengan penelitian Qamairah N, pada kawasan pemukiman di Bogor yang mendapatkan hasil perilaku buruk sebesar 27,11\%. ${ }^{7}$ Hasil ini juga sejalan dengan penelitian Octarient R, menilai perilaku higiene terkait keberadaan TDR pada penderita rhinitis alergi yang mendapatkan hasil buruk sebesar $60,8 \%{ }^{17}$ 


\section{SIMPULAN}

Seluruh tempat tinggal pasien DA RSUD Petala Bumi Pekanbaru tahun 2017 positifTDR dan ditemukan di seluruh ruang kamar. Derajat penyebaran TDR di tempat tinggal pasien DA tergolong tinggi dan perilaku higiene pasien DA tergolong buruk.

\section{DAFTAR PUSTAKA}

1. Widiastawan KA, Wahongan GJ, Bernadus JB. Jenis dan kepadatan tungau debu rumah di Kelurahan Malalayang Dua Kecamatan Malalayang Kota Manado. Jurnal e-Biomedik. 2015;3(3): 733-36.

2. Diana IS, Boediardja SA, Sugito TL, Lokanata MD, Prihianti S, Danarti R, et al. Panduan Diagnosis dan Tatalaksana Dermatitis Atopik di Indonesia. Edisi 1. Jakarta: Centra Communications; 2014: H. 1, 33-5.

3. Fitbryansah R. Identifikasi tungau debu rumah pada pasien asma RSUD Arifin Achmad Tahun 2016. [Skripsi]. Pekanbaru: Universitas Riau 2016.

4. Sugito TL, Boediardja SA, Wisesa TW, Prihianti $\mathrm{S}$, Agustin T. Buku panduan dermatitis atopik. Edisi 1. Jakarta: Badan Penerbit FKUI; 2011: H. $1-2,39-42$.

5. Davin. Profil penderita dermatitis atopik Di RSUP Haji Adam Malik Medan Periode 2014-2016. [Skripsi]. Medan: Universitas Sumatera Utara 2017.

6. Hadi UK. Tungau debu, Dermatophagoides. [diakses pada tanggal 21 Mei 2018]. Diunduh dari :http://upikke.staf.ipb.ac.id.

7. Qamairah N. Ragam jenis distribusi dan kelimpahan tungau debu rumah pada Wilayah Permukiman di Bogor. [Tesis]. Bogor : Institut Pertanian Bogor 2015.
8. Caldas EF, Puerta L, Caraballo L, Lockey RF. Mite allergens. J Allergy Clin Immunol. 2008 : 182-4.

9. BKPM Kota Pekanbaru. Ringkasan Pekanbaru. 2016. [diakses pada tanggal 21 Juli 2018]. Diunduh dari : https://regionalinvestment. bkpm.go.id/sipid/front/daerah/1471.

10.Sembel DT. Entomologi kedokteran. Widiyatmoko J, editor. Edisi 1. Yogyakarta: CV. ANDI OFFSET; 2009: H. 189-191.

11. Ponggalunggu WF, Pijoh VD, Wahongan GJ. Jenis dan kepadatan tungau debu rumah pada beberapa habitat di rumah penderita penyakit alergi. Jurnal e-Biomedik. 2015 ;3(1): 255-59.

12. Worang I, Sorisi A, Pijoh VD. Tungau debu rumah yang ditemukan di Kelurahan Titiwungen Selatan Kecamatan Sario Kota Manado. [Skripsi]. Manado : Universitas Sam Ratulangi; 2012.

13. Kokali FM. Tungau debu rumah di Kelurahan Ranotana Weru Kecamatan Wanea Kota Manado. Jurnal e-Biomedik. 2013;1(2): 977-80.

14. Sungkar S. Aspek biomedis tungau debu rumah. Majalah Kedokteran Indonesia. 2004;6(54): 22432.

15.Kristin SP, Tuda JS, Wahongan GJ. Jenis dan kepadatan tungau debu rumah di Kelurahan Malalayang 1 Kecamatan Malalayang Kota Manado. Jurnal e-Biomedik. 2015;3(3): 706-10.

16. Sutanto I, Ismid IS, Sjarifuddin PK, Sungkar S. Buku ajar parasitologi kedokteran. Edisi 4. Jakarta: Balai Penerbit FKUI; 2008: H. 288-91.

17. Octarient R. Identifikasi tungau debu rumah di tempat tinggal mahasiswa tingkat 3 dan 4 Fakultas Kedokteran Universitas Riau penderita rinitis alergi serta gambaran perilaku higienenya. [Skripsi]. Pekanbaru: Universitas Riau; 2016. 